bien pensant authors write slender books; Victorian readers could afford thick volumes of leisurely chatter and complacent display of solemn platitudes. To revive Whewell by a full reprint of his collected works is a misuse of the technical progress that makes such reprints so easy nowadays, a misuse only aggravated by including them among "classics of science".

For the historian of science, they have only the value of testimonies to the kind of ideology inculcated to the studious youth destined to occupy key positions in church and state, at a time when science appeared as a new, potentially dangerous social force that had to be tamed and harnessed. Whewell was the man destined to fulfil this task and, served by uncommon erudition and a shrewd turn of mind, he went about it with unsparing thoroughness. His industry, however, was not matched by his perspicacity. To realize how little he was actually au fait of the new trends of scientific thought, it will be sufficient to notice that such a fundamental idea as that of the correlation of the forces of nature was beyond his horizon. In fact, the scientific outlook he discusses at immoderate length was that following directly from Newton's work-carefully pruned, of course, of the epistemological innovations to which it gave rise under Locke's inspiration. $\mathrm{He}$ is also at pains to refute his French rival Auguste Comte, like himself erudite and shortsighted, but able at least to interpret the evolution of human thinking with an untrammelled mind.

L. ROSENFELD

\section{BERTALANFFY'S PSYCHOLOGY}

Robots, Men and Minds

Psychology in the Modern World. By Ludwig von Bertalanffy. Pp. $x+150$. (New York: George Braziller, Inc., 1967.) $\$ 5$.

This short book can be cordially recommended to students of psychology and psychiatry and also to those of their elders who, like me, have long been intrigued by the name of von Bertalanffy, without knowing exactly what he stands for. Such ignorance will certainly be dispelled by reading its lively text, which is interspersed at frequent intervals with citations from the author's publica. tions over the past forty-four years. It is a very personal book, and the personality which permeates it is not a particularly winning one: there is a constant strain of self-congratulation, coupled with an unconcealed resentment at the failure of the world of science to accord him the recognition which he feels he deserves. The author is clearly erudite, cultivated and brilliant; and yet every now and again he reveals a glimpse of the least attractive type of Teutonic authoritarianism-for example, in his unbridled scorn for beatniks, "unbearable" children, and "teenagers who do not know their mother tongue when entering college but are glued to the television screen for five hours a day"; and in his patronizing praise for an existentialist work by Simone de Beauvoir, "little as I like de Beauvoir's more sexy publications". Some readers may find him personally uncongenial; but none will find him dull. Throughout his life he seems to have been communing, both literally and in the realms of ideas, with many of the most original thinkers of our time. Both in his text, and in a long series of notes to the text, he succinctly presents (and frequently challenges) the ideas of men as diverse as Claude Bernard, Freud, Lorenz, Whitehead, and Toynbee, to name only a few.

His prime purpose, however, is to present an epitome of his own ideas; and these are full of interest. A distinguished biologist, he has fought a long guerilla warfare against the tyranny of inappropriate mechanistic thinking in the life sciences. He views cybernetics as the first major departure from the conceptual scheme of traditional physics, but believes that cybernetic models still cannot do full justice to the phenomena of living organisms, and particularly not to those involving symbol systems, as in human behaviour.

"Physical processes follow the second law of thermodynamics which prescribes that they proceed towards increasing entropy. . . But living systems apparently do exactly the opposite. In spite of irreversible processes continually going on, they tend to maintain an organized state of fantastic improbability; they are maintained in states of non-equilibrium; they even develop towards increasingly improbable states, increasing differentiation and order, as is manifest both in the individual development of an organism and in evolution from the famous amoeba to man".

The complexities of living organisms, especially the higher organisms, are such that, in his opinion, we need a conceptual approach as radically different from classical physics as was the Galilean from the Copernican view of the universe. He believes that in general systems theory we have the beginnings of such a new theoretical scheme, although he admits that perhaps some radically new mathematical discoveries will have to be made before this theory can be generalized to subsume all the complexities of living things.

In passing, von Bertalanffy executes a number of daring raids into several large topics. He rails against the "zoomorphizing" tendency of experimental psychology, the robotizing effect of the "doctrine of the primary reactivity of the psychophysiological organism"; and later he advances an alternative theory in which activity, and not reactivity, is seen as the basic characteristic of living creatures. He challenges the "random mutation" basis of neo-Darwinian evolutionary theory, and anticipates a new theory emerging from recent advances in molecular biology, advances which will reintroduce teleology into the evolutionary process. He points out that perception has been found to be not merely a response of the organism to external stimuli which impinge on it from the external world, but an active, selective process on the part of the organism itself. This leads to a reconsideration of the mind-body problem on lines reminiscent of Heisenberg's theory of complementary systems, which leads to the interesting suggestion that this problem is an attribute of the umwelt (or species-specific experience of the ambient reality, as described by von Uexküll) peculiar to human beings. This calls in turn for a new epistemology, in which an absolutistic is replaced by a perspective philosophy.

Not surprisingly, sociology also lends itself to analysis in terms of general systems theory: "Sociology is the study of social systems, whatever their exact definition may be". In this last phrase lies the weakness of his whole argument; because we are continually being asked to take on trust the claim that some day, in the future, the general theory of multiple interactions in open systems will be capable of actual application to biological, social and psychological events of extraordinary complexity. The author is well aware that he may be accused of being metaphysical, vitalistic, anti-scientific; but he insists that throughout his life he has been simply opposing the intrusion of pseudoscientific ways of thinking into fields of human experience where they do not belong. His aim, in contrast, has been to contribute towards the humanizing of science.

G. M. Carstairs

\section{EARLY MAN IN THE ARCTIC}

\section{Ancient Men of the Arctic}

By J. Louis Giddings. Pp. $\mathrm{xxxi}+391+\mathrm{xv}$. (London: Secker and Warburg, 1967.) 84s. net.

THIs book belongs to a genre increasingly popular in the United States, that of a personalized anecdotal account 